\title{
PENGARUH DESENTRALISASI FISKAL DALAM PENGENTASAN KEMISKINAN DENGAN PERTUMBUHAN EKONOMI SEBAGAI VARIABEL MEDIASI DI PROVINSI PAPUA
}

\author{
Shellenia Vitara Agatha' ${ }^{1)}$ Beta Andri Anggiano Uliansyah ${ }^{2)}$ \\ 1) shelleniavitara@gmail.com, Politeknik Keuangan Negara STAN* \\ 2) beta.uliansyah@pknstan.ac.id, Politeknik Keuangan Negara STAN
}

\begin{abstract}
Poverty alleviation is one of the objectives of development and justice. Papua Province is a province with very high poverty rate. This study aims to determine the effect of fiscal decentralization (PAD, DAU, DAK, Special Autonomy Fund, and capital expenditure) on poverty and the role of economic growth in mediating this effect. This research was conducted in districts/cities in Papua Province for 5 years (2015-2019 for the poverty rate and 2014-2018 for other variables). This study uses secondary data with fixed effect regression analysis and path analysis. The results show that simultaneously all independent variables affect dependent variable. Partially, DAU and DAK have a significant positive effect on economic growth; The Special Autonomy Fund has a positive and not significant effect on economic growth; PAD and capital expenditure have a significant negative effect on economic growth; DAU, DAK, and economic growth have a significant negative effect on poverty; The Special Autonomy Fund and capital expenditure have a negative and insignificant effect on poverty; PAD has a positive and not significant effect on poverty. In addition, the results of the indirect effect show that DAU and DAK have a negative and significant effect on poverty through economic growth as a mediating variable, while the Special Autonomy Fund has a negative and not significant effect, PAD has a positive and not significant effect, and capital expenditure has a positive and significant effect.
\end{abstract}

Keywords: fiscal decentralization, poverty, economic growth

\begin{abstract}
Abstrak
Penanggulangan kemiskinan merupakan salah satu sasaran dalam pemerataan pembangunan dan keadilan. Provinsi Papua merupakan provinsi dengan tingkat kemiskinan sangat tinggi. Penelitian ini bertujuan untuk mengetahui pengaruh desentralisasi fiskal (PAD, DAU, DAK, Dana Otonomi Khusus, dan belanja modal) terhadap kemiskinan dan peran pertumbuhan ekonomi dalam memediasi pengaruh tersebut. Penelitian ini dilakukan pada kabupaten/kota di Provinsi Papua selama 5 tahun yaitu 2015-2019 untuk tingkat kemiskinan dan 2014-2018 untuk variabel lainnya. Penelitian ini menggunakan data sekunder dengan analisis regresi fixed effect dan analisis jalur. Hasil penelitian menunjukkan bahwa semua variabel independen berpengaruh secara simultan terhadap variabel dependen. Secara parsial, DAU dan DAK berpengaruh positif signifikan terhadap pertumbuhan ekonomi; Dana Otonomi Khusus berpengaruh positif dan tidak signifikan terhadap pertumbuhan ekonomi; PAD dan belanja modal berpengaruh negatif signifikan terhadap pertumbuhan ekonomi; DAU, DAK, dan pertumbuhan ekonomi berpengaruh negatif signifikan terhadap kemiskinan; Dana Otonomi Khusus dan belanja modal berpengaruh negatif dan tidak signifikan terhadap kemiskinan; PAD berpengaruh positif dan tidak signifikan terhadap kemiskinan. Selain itu, hasil pengaruh tidak langsung menunjukkan bahwa DAU dan DAK berpengaruh negatif dan signifikan terhadap kemiskinan melalui pertumbuhan ekonomi sebagai variabel mediasi, sedangkan Dana Otonomi Khusus berpengaruh negatif dan tidak signifikan, PAD berpengaruh positif dan tidak signifikan, belanja modal berpengaruh positif dan signifikan.
\end{abstract}

Kata kunci: desentralisasi fiskal, kemiskinan, pertumbuhan ekonomi.

\section{PENDAHULUAN}

Kemiskinan merupakan isu global yang terjadi baik di negara maju maupun berkembang. Kemiskinan merupakan suatu masalah multidimensi berupa ketidakmampuan untuk mencapai akses ekonomi, sosial, politik, budaya, dan partisipasi dalam penduduk (Nurwati, 2008). Dalam menanggapi permasalahan kemiskinan, anggota Perserikatan Bangsa-Bangsa (PBB) sepakat menempatkan tujuan tanpa kemiskinan sebagai urutan pertama dalam Sustainable Development Goals (SDGs). Indonesia juga menjadikan penanggulangan kemiskinan sebagai salah satu sasaran dalam pemerataan pembangunan dan keadilan. Pada September 2019, persentase penduduk miskin 


\section{JURNALKU}

Volume 1 No. 3, September 2021

di Indonesia mengalami penurunan dan menunjukkan angka terendah selama era kemerdekaan yaitu sebesar 9,22 persen. Akan tetapi, beberapa provinsi di Indonesia mempunyai tingkat kemiskinan cukup tinggi. Menurut Kementerian PPN/Bappenas (2018), kriteria wilayah dengan kemiskinan tinggi yaitu tingkat kemiskinan lebih besar dari 15 persen selama tiga tahun berturutturut, tingkat penurunan kemiskinan mengalami perlambatan, dan terdapat permasalahan kemiskinan multidimensi. Pada periode September 2019, 16 dari 34 provinsi di Indonesia menunjukkan persentase penduduk miskin di atas rata-rata nasional dan enam provinsi menunjukkan persentase penduduk miskin di atas 15 persen. Provinsi Papua merupakan provinsi dengan persentase penduduk miskin tertinggi yakni 26,55 persen (Badan Pusat Statistik, 2020).

Provinsi Papua merupakan wilayah dengan tingkat kemiskinan yang cukup tinggi. Hal ini mendorong Provinsi Papua untuk melepas label ketertinggalan dan kemiskinan yang dinyatakan sebagai salah satu visi dalam RPJMD Papua 2013-2018 yaitu Papua Bangkit. Berdasarkan RPJMD Papua 2013-2018, target persentase penduduk miskin pada tahun 2018 sebesar 25 persen, sedangkan realisasinya sebesar 27,43 persen. Hal ini menunjukkan Provinsi Papua belum mampu memenuhi target yang telah ditetapkan. Selain itu, tingkat kemiskinan dalam lingkup regional kabupaten/kota di Provinsi Papua menunjukkan angka yang cukup tinggi. Pada periode Maret 2019, seluruh kabupaten/kota di Provinsi Papua memiliki persentase penduduk miskin yang lebih tinggi daripada Indonesia dan 17 kabupaten/kota di Provinsi Papua memiliki persentase penduduk miskin di atas rata-rata provinsi (Badan Pusat Statistik Provinsi Papua, 2020a). Perbedaan persentase tiap kabupaten/kota juga menunjukkan perbedaan yang cukup signifikan. Kabupaten Deiyai mempunyai persentase penduduk miskin tertinggi yaitu sebesar 43,65 persen dan Kabupaten Merauke mempunyai persentase penduduk miskin terendah yaitu sebesar 10,35 persen.

Perbedaan persentase penduduk miskin yang cukup tinggi pada kabupaten/kota di Provinsi Papua disebabkan oleh kondisi topografi dan sebaran penduduk yang tidak merata (Kementerian PPN/Bappenas, 2018). Hal ini ditunjukkan pada angka IKK Provinsi Papua yang paling tinggi di Indonesia yaitu sebesar 218,59 pada tahun 2019 (Badan Pusat Statistik, n.d.-b). Kesulitan geografis dan sebaran penduduk di Provinsi Papua mengakibatkan pergerakan penduduk terhambat, distribusi barang dan jasa mengalami kendala, akses terhadap pelayanan dasar terbatas, dan hasil pembangunan tidak merata (Kementerian PPN/Bappenas, 2018). Keterbatasan akses terhadap pelayanan dasar mengakibatkan rendahnya kualitas pendidikan, kesehatan, dan lingkungan di Papua. Hal ini akan mempengaruhi kualitas sumber daya manusia dan produktivitas manusia sehingga kehidupan penduduk di Papua tetap terbelakang dan sulit keluar dari kemiskinan.

Permasalahan kemiskinan itu memerlukan upaya penanggulangan bersama baik pemerintah pusat maupun daerah. Salah satu upaya pemerintah dalam mengatasi permasalahan kemiskinan yaitu penerapan otonomi daerah melalui pelaksanaan desentralisasi. Berdasarkan Undang-Undang Nomor 22 Tahun 1999 tentang Pemerintahan Daerah yang terakhir diubah dengan Undang-Undang Nomor 23 Tahun 2014 tentang Pemerintahan Daerah, daerah otonom memiliki hak, wewenang, dan kewajiban untuk mengurus sendiri urusan pemerintahan dan kepentingan penduduknya. Salah satu komponen desentralisasi adalah desentralisasi fiskal. Hal ini didasarkan pada Undang-Undang Nomor 25 Tahun 1999 tentang Perimbangan Keuangan antara Pemerintah Pusat dan Pemerintahan Daerah yang terakhir diubah dengan Undang-Undang Nomor 33 tahun 2004 tentang Perimbangan Keuangan antara Pemerintah dan Pemerintahan Daerah. Dalam pelaksanaan desentralisasi fiskal, pemerintah daerah berhak memperoleh sumber keuangan yang cukup dan mempunyai kewenangan mengatur penggunaannya (Sidik, 2002b). Pendapatan Asli Daerah (PAD) merupakan salah satu sumber keuangan yang memberikan kebebasan kepada daerah dalam menggali potensi daerahnya sesuai peraturan daerah sehingga dapat digunakan untuk memenuhi kebutuhan daerah. Selain itu, 


\section{JURNALKU}

Volume 1 No. 3, September 2021

pemerintah daerah mendapatkan dana transfer dari pemerintah pusat, antara lain Dana Alokasi Umum (DAU) dan Dana Alokasi Khusus (DAK). DAU merupakan dana transfer yang pemanfaatannya diserahkan sepenuhnya kepada daerah. Sementara itu, DAK merupakan dana transfer yang sudah ditentukan penggunaannya. Pemerintah Daerah Papua juga mendapatkan Dana Otonomi Khusus (DOK) sejak diberlakukannya Undang-Undang Nomor 21 Tahun 2001 tentang Otonomi Khusus Bagi Provinsi Papua.

Pemerintah daerah juga mengalokasikan belanja daerah sebagai pelaksanaan desentralisasi fiskal dari sisi pengeluaran untuk mengurangi permasalahan kemiskinan. Alokasi belanja produktif dan penyerapan anggaran yang lebih baik diharapkan menciptakan multiplier effect sehingga berdampak terhadap kualitas layanan publik, pertumbuhan ekonomi, dan pengentasan kemiskinan (Kementerian Keuangan, 2020). Akan tetapi, kebijakan desentralisasi fiskal belum tentu langsung mempengaruhi tingkat kemiskinan. Hal ini diperlukan variabel lain sebagai mediator yaitu pertumbuhan ekonomi. Menurut Sudewi dan Wirathi (2013), desentralisasi fiskal dapat mengurangi jumlah penduduk miskin jika diikuti kenaikan pendapatan perkapita sebagai ukuran adanya pertumbuhan ekonomi. Sepulveda dan Martinez-Vazquez (2011) juga menyatakan bahwa desentralisasi fiskal mempunyai pengaruh tidak langsung terhadap kemiskinan melalui pertumbuhan ekonomi. Pertumbuhan ekonomi yang berkualitas dapat menyerap tenaga kerja dan mengurangi kemiskinan (Kementerian Keuangan, 2020).

Berdasarkan hasil penelitian terdahulu, hasil yang beragam disebabkan oleh perbedaan kondisi dan kemampuan daerah. Selain itu, pelaksanaan desentralisasi yang didanai dengan beberapa kombinasi sumber keuangan pemerintah mempunyai pengaruh yang berbeda terhadap kemiskinan (Sepulveda dan Martinez-Vazquez, 2011). Hal ini yang melatarbelakangi penulis melakukan penelitian ini. Tujuan penelitian ini untuk mengetahui pengaruh PAD, DAU, DAK, Dana Otonomi Khusus, dan belanja modal terhadap pertumbuhan ekonomi; pengaruh PAD, DAU, DAK, Dana Otonomi Khusus, belanja modal, dan pertumbuhan ekonomi terhadap kemiskinan; pengaruh PAD, DAU, DAK, Dana Otonomi Khusus, dan belanja modal terhadap kemiskinan melalui pertumbuhan ekonomi sebagai variabel mediasi pada pemerintah kabupaten/kota di Provinsi Papua.

\section{KAJIAN PUSTAKA}

\section{Teori Federalisme Fiskal}

Menurut Musgrave (1959, dikutip dalam Vo, 2010), teori federalisme fiskal menekankan pada efisiensi penggunaan sumber daya oleh pemerintah daerah yang dapat memaksimalkan kesejahteraan para pemilihnya. Oates (1999) menyatakan bahwa kesejahteraan ekonomi dapat dicapai ketika output barang dan jasa disediakan oleh tingkat pemerintahan terendah karena dianggap lebih mengetahui preferensi lokal, lebih dekat dengan penduduk, dan lebih memahami kondisi daerahnya daripada pemerintah pusat. Menurut Oates (1999), teori ini beranggapan bahwa adanya keterbatasan informasi terkait kebutuhan dan biaya setiap daerah mendorong pemerintah pusat cenderung menghasilkan output yang sama untuk tiap wilayah yang menyebabkan kesejahteraan tidak tercapai karena tuntutan dari penduduk yang berbeda.

\section{Kemiskinan}

Menurut Kadji (2012), kemiskinan merupakan kondisi ketika manusia tidak mampu memenuhi kebutuhan dasarnya yang mencakup aspek primer seperti pengetahuan dan keterampilan serta aspek sekunder seperti sumber keuangan, kecukupan gizi, kualitas air, perumahan, fasilitas kesehatan, fasilitas pendidikan, dan jaringan sosial. Badan Pusat Statistik (n.d.-c) mendefinisikan kemiskinan sebagai ketidakmampuan ekonomi yang diukur dari sisi 


\section{JURNALKU}

Volume 1 No. 3, September 2021

pengeluaran dalam memenuhi kebutuhan dasar makanan dan bukan makanan. Pengukuran kemiskinan oleh Badan Pusat Statistik (BPS) menggunakan konsep kemiskinan absolut yang berhubungan dengan kemampuan manusia dalam memenuhi kebutuhan dasarnya yang tercermin dalam garis kemiskinan. Penduduk miskin adalah penduduk dengan rata-rata pengeluaran per kapita per bulan di bawah garis kemiskinan.

\section{Teori Lingkaran Setan Kemiskinan}

Menurut Nurkse (1971), lingkaran setan kemiskinan merupakan suatu konsep yang menjelaskan bahwa kemiskinan disebabkan oleh berbagai hal yang saling berhubungan seperti rendahnya produktivitas menyebabkan rendahnya pendapatan, rendahnya pendapatan dapat menyebabkan rendahnya investasi dan tabungan, dan rendahnya investasi atau tabungan dapat menyebabkan rendahnya produktivitas. Penyebab kemiskinan itu saling berkaitan dan menyebabkan suatu wilayah miskin akan tetap miskin.

\section{Pertumbuhan Ekonomi}

Menurut Kuznets (1973), pertumbuhan ekonomi merupakan peningkatan kapasitas produksi dari suatu negara dalam jangka panjang untuk menyediakan berbagai barang ekonomi untuk penduduknya. Badan Pusat Statistik (n.d.-d) mendefinisikan pertumbuhan ekonomi sebagai perkembangan produksi barang dan jasa pada tahun tertentu terhadap nilai tahun sebelumnya di suatu wilayah perekonomian. Badan Pusat Statistik mengukur pertumbuhan ekonomi berdasarkan Produk Domestik Bruto (PDB). Secara regional, PDB disebut sebagai Produk Domestik Regional Bruto (PDRB). BPS menghitung PDB/PDRB atas dasar harga konstan yaitu nilai barang dan jasa dihitung dengan harga yang berlaku pada tahun tertentu sebagai dasar.

Berdasarkan teori trickle down effect yang dikembangkan oleh Arthur Lewis (1954, dikutip dalam Soleh, 2015), pertumbuhan ekonomi akan berpengaruh terhadap kemiskinan melalui kemajuan sekelompok penduduk yang membelanjakan hasil pertumbuhan ekonomi yang diterimanya sehingga dapat menciptakan lapangan kerja dan mendistribusikan hasil pertumbuhan ekonomi yang merata. Pertumbuhan ekonomi ini dipengaruhi oleh campur tangan pemerintah. Berdasarkan teori Keynes yang dikemukakan oleh John Maynard Keynes, kebijakan pemerintah dapat mengurangi kesulitan ekonomi (Mankiw, 2016). Teori Keynes menyatakan bahwa rendahnya permintaan agregat berpengaruh terhadap kemerosotan ekonomi yang ditandai dengan tingkat pendapatan rendah dan tingkat pengangguran tinggi (Mankiw, 2016). Keynes berpendapat bahwa dalam jangka pendek permintaan agregat akan mempengaruhi pendapatan nasional yang ditentukan oleh pengeluaran rumah tangga, perusahaan, dan pemerintah (Mankiw, 2016). Keynes mempertimbangkan bahwa kebijakan konsumsi pemerintah melalui belanja pemerintah memiliki multiplier effect terhadap pendapatan nasional yang dapat meningkatkan pertumbuhan ekonomi.

\section{Desentralisasi Fiskal}

Berdasarkan Undang-Undang Nomor 33 Tahun 2004 tentang Perimbangan Keuangan antara Pemerintah Pusat dan Pemerintahan Daerah, desentralisasi merupakan penyerahan wewenang pemerintahan oleh pemerintah kepada daerah otonom untuk mengatur dan mengurus urusan pemerintahan dalam sistem Negara Kesatuan Republik Indonesia. Menurut Bahl (2008), desentralisasi fiskal terdiri atas expenditure assignment, revenue assignment, dan intergovernmental transfers sebagai bentuk pengalihan kewenangan anggaran dari pemerintah pusat kepada pemerintah daerah dalam membuat keputusan mengenai pendapatan dan pengeluaran.

a. PAD merupakan pendapatan daerah yang dipungut berdasarkan peraturan daerah sesuai dengan peraturan perundang-undangan. Sumber-sumber PAD berasal dari pajak daerah, retribusi daerah, hasil pengelolaan kekayaan daerah yang dipisahkan, dan lain lain PAD yang sah. 


\section{JURNALKU}

Volume 1 No. 3, September 2021

b. DAU merupakan dana dari APBN yang dialokasikan untuk pemerataan kemampuan keuangan antardaerah dalam mendanai kebutuhan daerah sebagai bentuk pelaksanaan desentralisasi. DAU bersifat block grant yaitu penggunaannya diserahkan kepada pemerintah daerah berdasarkan prioritas dan kebutuhan daerah untuk meningkatkan pelayanan kepada penduduk.

c. DAK merupakan dana dari APBN yang dialokasikan kepada daerah tertentu untuk mendanai kegiatan khusus yang menjadi urusan daerah dan prioritas nasional, khususnya untuk memenuhi kebutuhan sarana dan prasarana pelayanan dasar penduduk. Hal ini menunjukkan DAK sebagai specific grant yaitu jenis transfer yang penggunaannya telah ditetapkan untuk tujuan tertentu.

d. Dana Otonomi Khusus merupakan dana yang diberikan kepada Provinsi Papua untuk melaksanakan otonomi khusus. Berdasarkan Peraturan Daerah Khusus Provinsi Papua Nomor 13 tahun 2016 tentang Perubahan Atas Peraturan Daerah Khusus Provinsi Papua Nomor 25 Tahun 2013 tentang Pembagian Penerimaan dan Pengelolaan Keuangan Dana Otonomi Khusus, otonomi khusus yaitu kewenangan yang diakui dan diberikan khusus kepada Provinsi Papua untuk mengurus dan mengatur sendiri kepentingan penduduknya sesuai aspirasi dan hakhak dasar penduduknya.

e. Belanja modal berdasarkan Peraturan Pemerintah Republik Indonesia Nomor 12 Tahun 2019 merupakan belanja untuk mendapatkan aset tetap dan aset lainnya yang mempunyai manfaat lebih dari satu periode akuntansi. Kriterianya adalah mempunyai masa manfaat lebih dari 12 bulan, mempunyai batas minimal kapitalisasi aset yang diatur dalam peraturan kepala daerah, dan digunakan dalam kegiatan pemerintahan daerah.

\section{Penelitian Terdahulu}

Jolianis (2016) melakukan penelitian mengenai pengaruh PAD, DAU, dan DAK terhadap kemiskinan dengan pertumbuhan ekonomi sebagai variabel intervening tahun 2010 hingga 2014 pada kabupaten/kota di Sumatera Barat. Hasilnya adalah PAD dan DAU berpengaruh signifikan terhadap pertumbuhan ekonomi dan kemiskinan, DAK tidak berpengaruh terhadap pertumbuhan ekonomi dan kemiskinan. Widianto et al. (2016) melakukan penelitian mengenai pengaruh DAU, DAK, dan belanja modal terhadap pertumbuhan ekonomi dan tingkat kemiskinan di Kota Tegal. Hasilnya adalah DAU, DAK, dan belanja modal tidak berpengaruh terhadap pertumbuhan ekonomi; DAK dan pertumbuhan ekonomi mempunyai pengaruh signifikan terhadap kemiskinan; belanja modal tidak berpengaruh terhadap kemiskinan. Safitri dan Saleh (2020) juga melakukan penelitian mengenai pengaruh belanja modal terhadap kemiskinan di Provinsi Kalimantan Selatan selama tahun 2008 hingga 2017. Hasilnya adalah belanja modal mempunyai pengaruh negatif signifikan terhadap kemiskinan. Anwar et al. (2018) melakukan penelitian mengenai pengaruh PAD, Dana Otonomi Khusus dan belanja modal terhadap PDRB pada kabupaten/kota di Provinsi Papua selama tahun 2011 hingga 2015. Hasilnya adalah PAD dan Dana Otonomi Khusus mempunyai pengaruh positif signifikan sementara belanja modal mempunyai pengaruh negatif signifikan terhadap pertumbuhan ekonomi. Muliadi dan Amri (2019) melakukan penelitian mengenai Dana Otonomi Khusus terhadap penurunan kemiskinan di Aceh selama tahun 2011 sampai 2016. Hasilnya adalah Dana Otonomi Khusus berpengaruh negatif signifikan terhadap kemiskinan. 


\section{JURNALKU}

Volume 1 No. 3, September 2021

\section{Kerangka Pemikiran}

\section{Gambar 1. Kerangka Pemikiran}

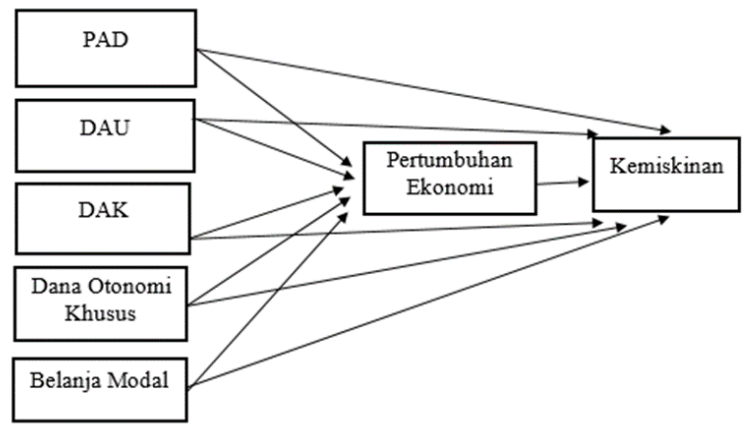

Sumber: diolah penulis (2021)

Dari penyebab terjadinya kemiskinan yang berujung dalam teori lingkaran setan kemiskinan, cara mengentaskan kemiskinan yaitu dengan memutus rantai tersebut. Pemutusan rantai lingkaran kemiskinan memerlukan peran pemerintah baik pemerintah pusat maupun daerah. Pemerintah perlu mengambil langkah intervensi ekonomi sebagaimana teori Keynes. Peran pemerintah dalam pengentasan kemiskinan ditunjukkan dalam pelaksanaan desentralisasi fiskal baik dari sisi pendapatan maupun pengeluaran. Hal ini dilandasi oleh teori federalisme fiskal yang menjelaskan bahwa pemerintah daerah mampu meningkatkan kesejahteraan penduduk yang akan berdampak pada penurunan kemiskinan melalui alokasi sumber daya secara efisien dan menyediakan layanan publik sesuai preferensi publik.

Dalam pelaksanaan desentralisasi fiskal dari sisi pendapatan, pemerintah daerah memerlukan sumber keuangan yang memadai untuk menyediakan layanan publik dan mengentaskan kemiskinan. Desentralisasi fiskal dari sisi pendapatan antara lain PAD, DAU, DAK, dan Dana Otonomi Khusus. PAD merupakan sumber keuangan yang diperoleh dari potensi daerahnya. Semakin besar PAD, semakin besar kemampuan daerah mendanai kebutuhan daerahnya sendiri. DAU, DAK, dan Dana Otonomi Khusus merupakan transfer pemerintah pusat yang menjadi sumber keuangan pemerintah daerah untuk memastikan bahwa daerah mempunyai dana yang cukup dalam mendanai kebutuhan daerahnya termasuk layanan publik dan program pengentasan kemiskinan. Dalam pelaksanaan desentralisasi fiskal dari sisi pengeluaran, pemerintah daerah mempunyai wewenang untuk mengatur belanja daerah. Salah satu belanja daerah adalah belanja modal. Belanja modal merupakan bentuk pengeluaran pemerintah daerah berkaitan dengan penyediaan layanan publik. Salah satu penyebab kemiskinan di Provinsi Papua yaitu keterbatasan layanan publik. Oleh karena itu, alokasi belanja modal dapat digunakan untuk mengurangi kemiskinan dengan menyediakan layanan publik bagi penduduk miskin. Pelaksanaan desentralisasi fiskal diharapkan memiliki trickle down effect yang optimal. Teori Keynes menjelaskan bahwa pengeluaran pemerintah dapat meningkatkan pertumbuhan ekonomi. Kenaikan belanja pemerintah dapat meningkatkan permintaan produksi barang dan jasa. Akibatnya, permintaan tenaga kerja meningkat dan pendapatan meningkat sehingga mampu untuk memenuhi kebutuhan hidup dan menurunkan kemiskinan.

\section{Hipotesis Penelitian}

Berdasarkan teori dan penelitian terdahulu, hipotesis pada penelitian ini yaitu PAD berpengaruh positif terhadap pertumbuhan ekonomi, DAU berpengaruh positif terhadap pertumbuhan ekonomi, DAK berpengaruh positif terhadap pertumbuhan ekonomi. Dana Otonomi Khusus berpengaruh positif terhadap pertumbuhan ekonomi, Belanja modal berpengaruh positif 


\section{JURNALKU}

Volume 1 No. 3, September 2021

terhadap pertumbuhan ekonomi, PAD berpengaruh negatif terhadap kemiskinan, DAU berpengaruh negatif terhadap kemiskinan, DAK berpengaruh negatif terhadap kemiskinan, Dana Otonomi Khusus berpengaruh negatif terhadap kemiskinan, belanja modal berpengaruh negatif terhadap kemiskinan, pertumbuhan ekonomi berpengaruh negatif terhadap kemiskinan, PAD berpengaruh negatif terhadap kemiskinan melalui pertumbuhan ekonomi, DAU berpengaruh negatif terhadap kemiskinan melalui pertumbuhan ekonomi, DAK berpengaruh negatif terhadap kemiskinan melalui pertumbuhan ekonomi, Dana Otonomi Khusus berpengaruh negatif terhadap kemiskinan melalui pertumbuhan ekonomi, belanja modal berpengaruh negatif terhadap kemiskinan melalui pertumbuhan ekonomi.

\section{METODE}

Jenis Data

Jenis data dalam penelitian ini merupakan data sekunder. yaitu data persentase penduduk miskin kabupaten/kota di Provinsi Papua periode 2015-2019 dari situs resmi Badan Pusat Statistik (BPS); data PDRB atas harga konstan 2010 kabupaten/kota di Provinsi Papua periode 2014-2018 dari situs resmi BPS; data realisasi PAD, DAU, DAK, Dana Otonomi Khusus, dan belanja modal periode 2014-2018 dari Laporan Realisasi Anggaran (LRA) dalam Laporan Hasil Pemeriksaan (LHP) atas Laporan Keuangan Pemerintah Daerah (LKPD) yang diperoleh melalui Badan Pemeriksa Keuangan. Penelitian ini menggunakan data panel yaitu gabungan antara data cross section dan time series. Data cross section mencakup kabupaten/kota di Provinsi Papua. Data time series mencakup periode tahun 2015 hingga 2019 untuk tingkat kemiskinan dan tahun 2014 hingga 2018 untuk PAD, DAU, DAK, Dana Otonomi Khusus, belanja modal, dan pertumbuhan ekonomi. Adanya jeda waktu antara variabel dependen dengan variabel independen dan variabel mediasi karena perhitungan persentase penduduk miskin dilakukan setiap bulan Maret untuk kabupaten/kota.

\section{Teknik Pengambilan Sampel}

Teknik pengambilan sampel dalam penelitian ini adalah nonprobability sampling dengan metode purposive sampling yaitu sampel diperoleh berdasarkan kriteria tertentu. Kriteria sampel dalam penelitian ini adalah pemerintah kabupaten/kota di Provinsi Papua yang mempunyai nilai persentase penduduk miskin tahun 2015-2019; PDRB atas harga konstan pada tahun 2014-2018; data realisasi PAD, DAU, DAK, Dana Otonomi Khusus, dan belanja modal tahun 2014-2018. Dalam penelitian ini, Kabupaten Nduga dikeluarkan dari sampel penelitian karena tidak terdapat data Susenas Maret 2015 di Kabupaten Nduga dan angka yang tertera di BPS menggunakan data Susenas Maret 2014 (Badan Pusat Statistik Provinsi Papua, 2020b).

\section{Variabel Penelitian dan Definisi Operasional}

a. Variabel dependen dalam penelitian ini adalah kemiskinan yang diukur dengan persentase penduduk miskin.

b. Variabel independen dalam penelitian ini adalah PAD, DAU, DAK, DOK, dan belanja modal yang diukur dengan logaritma natural dari nilai realisasinya,

c. Variabel mediasi dalam penelitian ini adalah pertumbuhan ekonomi yang diukur menggunakan PDRB atas harga konstan tahun 2010 dalam miliar rupiah kemudian dilakukan transformasi data ke dalam bentuk logaritma natural.

\section{Metode Analisis Data}

Penelitian ini menggunakan regresi data panel dan analisis jalur. Berdasarkan analisis jalur, persamaan struktural dalam penelitian ini dibagi menjadi dua, yakni sebagai berikut. 
Model Persamaan I $\begin{aligned} \operatorname{LnPDRB}_{i t}= & \alpha+p_{1} \ln P A D_{i t}+p_{2} \ln D A U_{i t}+p_{3} \ln D A K_{i t}+p_{4} \ln D O K_{i t}+p_{5} \ln B M_{i t} \\ & +\varepsilon_{1}(I)\end{aligned}$

Model Persamaan II

$$
\begin{aligned}
K M S_{i t}=\alpha & +p_{6} \ln P A D_{i t-1}+p_{7} \ln D A U_{i t-1}+p_{8} \ln D A K_{i t-1}+p_{9} \ln D O K_{i t-1}+p_{10} \ln B M_{i t-1} \\
& +p_{11} \ln P D R B_{i t-1}+\varepsilon_{2}(I I)
\end{aligned}
$$

HASIL DAN PEMBAHASAN

\begin{tabular}{ccccc}
\hline Model & Effects Test & Statistic & d.f. & Prob. \\
\hline Persamaan I & Cross-section F & 565,482915 & $(27,107)$ & 0,0000 \\
\cline { 2 - 5 } & Cross-section Chi-square & 695,474049 & 27 & 0,0000 \\
\hline Persamaan II & Cross-section F & 412,707259 & $(27,106)$ & 0,0000 \\
\cline { 2 - 5 } & Cross-section Chi-square & 653,044553 & 27 & 0,0000 \\
\hline
\end{tabular}

\section{Pemilihan Model Data Panel}

Pemilihan model data panel dilakukan dengan beberapa uji. Uji chow dilakukan untuk menentukan model regresi yang lebih tepat digunakan antara model PLS dengan FE.

\section{Tabel 1. Hasil Uji Chow}

Sumber: diolah dari output Eviews 9 (2021)

Berdasarkan hasil uji chow pada Tabel 1 nilai probabilitas model persamaan I dan II lebih kecil dari 0,05 yaitu 0,0000 sehingga $\mathrm{H} 0$ ditolak. Jadi, FE lebih tepat digunakan dalam model persamaan I dan II daripada PLS. Selanjutnya, uji hausman dilakukan untuk memperoleh model regresi yang lebih baik digunakan antara model RE dengan FE.

\section{Tabel 2. Hasil Uji Hausman}

\begin{tabular}{ccccc}
\hline Model & Test Summary & Chi-Sq. Statistic & Chi-Sq. d.f. & Prob. \\
\hline Persamaan I & Cross-section random & 93,323691 & 5 & 0,0000 \\
\hline Persamaan II & Cross-section random & 35,282361 & 6 & 0,0000 \\
\hline
\end{tabular}

Sumber: diolah dari output Eviews 9 (2021)

Berdasarkan hasil uji hausman pada Tabel 2, nilai probabilitas model persamaan I yaitu 0,0000 dan nilai probabilitas model persamaan II yaitu 0,0000 . Nilai probabilitas kedua model persamaan lebih kecil dari 0,05 sehingga $\mathrm{H} 0$ ditolak. Jadi, FE lebih tepat digunakan dalam model persamaan I dan II daripada RE.

\section{Pengujian Asumsi Klasik}

\section{Uji Normalitas}

Uji normalitas dilakukan dengan uji Jarque-Bera. Nilai probabilitas persamaan I lebih besar dari 0,05 yaitu 0,233653 sehingga model persamaan I terdistribusi secara normal. Sementara itu, nilai probabilitas persamaan II lebih kecil dari 0,05 yaitu 0,00089 sehingga model persamaan II tidak terdistribusi secara normal. Akan tetapi, residual dalam model persamaan II diasumsikan terdistribusi normal berdasarkan Central Limit Theorema, yaitu data diasumsikan terdistribusi normal jika ukuran sampel lebih dari 100 (Gujarati, 2004). 


\section{JURNALKU}

Volume 1 No. 3, September 2021

Uji Multikolinieritas

Gambar 2. Hasil Uji Multikolinieritas

\begin{tabular}{||cc||}
\hline \hline Variable & $\begin{array}{c}\text { Centered } \\
\text { VIF }\end{array}$ \\
\hline \hline C & NA \\
LNPAD & 1.277723 \\
LNDAU & 1.381464 \\
LNDAK & 1.320833 \\
LNDOK & 1.152985 \\
LNBM & 1.295876 \\
\hline
\end{tabular}

Model Persamaan I

\begin{tabular}{||cc||}
\hline \hline Variable & $\begin{array}{c}\text { Centered } \\
\text { VIF }\end{array}$ \\
\hline \hline C & NA \\
LNPAD & 3.556752 \\
LNDAU & 1.390738 \\
LNDAK & 1.323110 \\
LNDOK & 1.258919 \\
LNBM & 1.307359 \\
LNPDRB & 3.318841 \\
\hline
\end{tabular}

Model Persamaan II

Sumber:

output Eviews 9 (2021)

Uji multikolinieritas dilakukan menggunakan nilai VIF. Berdasarkan Gambar 2, hasil nilai VIF model persamaan I dan II lebih kecil dari 10. Hal ini menjelaskan bahwa model persamaan I dan II tidak terdapat gejala multikolinieritas.

Uji Heteroskedastisitas

\section{Gambar 3. Hasil Uji Heteroskedastisitas}

\begin{tabular}{|c|c|c|c|c|}
\hline \multicolumn{5}{|c|}{$\begin{array}{l}\text { Dependent Variable: RESABS } \\
\text { Method: Panel Least Squares } \\
\text { Date: } 07 / 09 / 21 \text { Time: } 17: 54 \\
\text { Sample: } 20142018 \\
\text { Periods included: } 5 \\
\text { Cross-sections included: } 28 \\
\text { Total panel (balanced) observations: } 140\end{array}$} \\
\hline Variable & Coefficient & Std. Error & t-Statistic & Prob. \\
\hline$\stackrel{\text { C }}{\mathrm{C}}$ & $\begin{array}{r}-0.295198 \\
-0.001356\end{array}$ & $\begin{array}{l}0.489821 \\
0.006531\end{array}$ & $\begin{array}{l}-0.602666 \\
-0.207661\end{array}$ & $\begin{array}{l}0.5480 \\
0.8359\end{array}$ \\
\hline LNDAU & 0.036741 & 0.062049 & 0.592119 & 0.5550 \\
\hline LNDAK & 0.015266 & 0.010659 & 1.432248 & 0.1550 \\
\hline LNDOK & 0.036793 & 0.048412 & 0.760007 & 0.4489 \\
\hline LNBM & -0.025928 & 0.011147 & -2.325998 & 0.0219 \\
\hline
\end{tabular}

Model Persamaan I

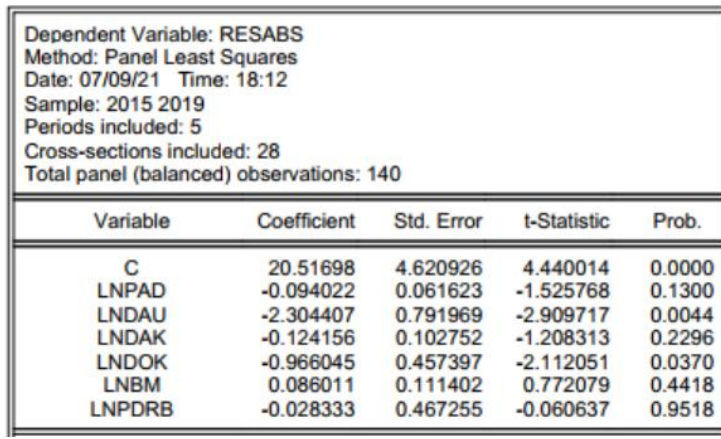

Model Persamaan II

Sumber: output Eviews 9 (2021)

Uji heteroskedastisitas dilakukan menggunakan uji Glejser. Berdasarkan Gambar 3, nilai probabilitas model persamaan I dan II lebih kecil dari 0,05. Hal ini menjelaskan model persamaan I dan II terdapat masalah heteroskedastisitas. Dalam eviews, permasalahan heteroskedastisitas dapat diatasi menggunakan metode Generalized Least Squared dengan opsi cross-section weights karena lebih layak digunakan ketika jumlah cross section lebih besar dari jumlah periode waktu (Eviews, 2017).

Uji Autokorelasi

Uji autokorelasi dilakukan dengan uji Durbin-Watson. Berdasarkan Tabel 3, nilai DurbinWatson model persamaan I lebih kecil dari du sehingga model persamaan I terdapat autokorelasi. Permasalahan autokorelasi dapat diatasi menggunakan robust variance matrix melalui opsi white periode pada menu coef covariance method (Eviews, 2017). Sementara itu, nilai Durbin-Watson persamaan II lebih besar dari du dan lebih kecil dari 4-du sehingga model persamaan II tidak terdapat gejala autokorelasi. 
Tabel 3. Hasil Uji Autokorelasi

\begin{tabular}{c|c|c}
\hline Keterangan & Model Persamaan I & Model Persamaan II \\
\hline Durbin-Watson & 1,333558 & 2,082025 \\
\hline $\mathrm{Du}$ & 1,79836 & 1,81397 \\
\hline $4-\mathrm{du}$ & 2,20164 & 2,18603 \\
\hline
\end{tabular}

\section{Hasil Uji Statistik}

Sumber: diolah dari output Eviews 9 (2021)

\section{Model Persamaan I}

$$
\begin{aligned}
& \operatorname{LnPDRB}_{i t}=0,149813-0,015423 \ln \mathrm{PAD}_{\text {it }}+1,138152 \operatorname{lnDAU} \mathrm{U}_{\text {it }}+0,053794 \operatorname{lnDAK} \text { it } \\
& +0,068217 \operatorname{lnDOK}_{\mathrm{it}}-0,091066 \operatorname{lnBM}_{\mathrm{it}}+0,766828(\mathrm{I})
\end{aligned}
$$

Tabel 4. Ringkasan Hasil Uji Regresi Model Persamaan I

\begin{tabular}{ccccccc}
\hline Variabel & $\begin{array}{c}\text { Prediksi } \\
\text { Arah }\end{array}$ & Coef & $\begin{array}{c}\text { Standar } \\
\text { error }\end{array}$ & t hitung & $\begin{array}{c}\text { Prob (two- } \\
\text { tailed) }\end{array}$ & $\begin{array}{c}\text { Prob (one- } \\
\text { tailed) }\end{array}$ \\
\hline Cons & $?$ & 0,149813 & 0,766828 & 0,195367 & 0,8455 & $0,42275^{* *}$ \\
\hline LNPAD & + & $\begin{array}{c}- \\
0,015423\end{array}$ & 0,007698 & $-2,003595$ & 0,0476 & $0,0238^{* *}$ \\
\hline LNDAU & + & 1,138152 & 0,100627 & 11,31061 & 0,0000 & $0,00005^{* *}$ \\
\hline LNDAK & + & 0,053794 & 0,020264 & 2,654619 & 0,0092 & $0,0046^{* *}$ \\
\hline LNDOK & + & 0,068217 & 0,070697 & 0,964915 & 0,3368 & $0,1684^{* *}$ \\
\hline LNBM & + & $\begin{array}{c}- \\
0,091066\end{array}$ & 0,025805 & $-3,529026$ & 0,0006 & $0,0003^{* *}$ \\
\hline Adjusted R ${ }^{2}: 0,997330$ & & \multicolumn{3}{c}{ Prob F: 0,0000}
\end{tabular}

Keterangan: tanda $* *$ menunjukkan tingkat signifikansi 0,05

Keputusan: nilai probabilitas $<0,05$ atau nilai $\mathrm{t}$ tabel $(1,65)<\mathrm{t}$ hitung, maka signifikan

Sumber: diolah dari output Eviews (2021)

Nilai adjusted $\mathrm{R}^{2}$ model persamaan I sebesar 0,997330, artinya variabel PAD, DAU, DAK, Dana Otonomi Khusus, dan belanja modal dapat menjelaskan PDRB sebesar 99,73 persen. Selisihnya sebesar 0,27 persen dijelaskan oleh variabel lain di luar model persamaan I. Hasil uji F model persamaan I menunjukkan nilai probabilitas lebih kecil dari 0,05 yaitu sebesar 0,0000. Hal ini diinterpretasikan bahwa variabel PAD, DAU, DAK, Dana Otonomi Khusus, dan belanja modal berpengaruh secara simultan atau bersama-sama terhadap PDRB.

Hipotesis dalam penelitian ini merupakan hipotesis pengujian satu arah atau one-tailed test. Nilai probabilitas yang dihasilkan oleh aplikasi menggunakan prinsip two-tailed test (Eviews, 2017). Jadi, hasil probabilitas two-tailed test perlu diubah menjadi one-tailed test dengan cara membagi dua hasilnya. Berdasarkan nilai probailitas dan uji t, PAD dan belanja modal berpengaruh negatif dan signifikan terhadap PDRB;.DAU dan DAK berpengaruh positif signifikan terhadap PDRB; Dana Otonomi Khusus tidak berpengaruh signifikan terhadap PDRB.

Model Persamaan II

$$
\begin{aligned}
\mathrm{KMS}_{\mathrm{it}}=68,07973+0,075160 \operatorname{lnPAD}_{\mathrm{it}-1}-3,849246 \operatorname{lnDAU}_{\mathrm{it}-1}-0,245885 \operatorname{lnDAK}_{\mathrm{it}-1} \\
\\
-0,070780 \operatorname{lnDOK} \mathrm{K}_{\mathrm{it}-1}-0,023270 \operatorname{lnBM}_{\mathrm{it}-1}-1,648222 \operatorname{lnPDB}_{\mathrm{it}-1} \\
+6,287552 \text { (II) }
\end{aligned}
$$


Tabel 5. Ringkasan Hasil Uji Regresi Model Persamaan II

\begin{tabular}{lcccccc}
\hline Variabel & $\begin{array}{c}\text { Prediksi } \\
\text { Arah }\end{array}$ & Coef & $\begin{array}{c}\text { Standar } \\
\text { error }\end{array}$ & thitung & $\begin{array}{c}\text { Prob (two- } \\
\text { tailed) }\end{array}$ & $\begin{array}{c}\text { Prob (one- } \\
\text { tailed) }\end{array}$ \\
\hline Cons & $?$ & 68,07973 & 6,287552 & 10,82770 & 0,0000 & $0,00005^{* *}$ \\
\hline LNPAD & - & 0,075160 & 0,096959 & 0,775171 & 0,4400 & $0,22^{* *}$ \\
\hline LNDAU & - & $-3,849246$ & 0,973373 & $-3,954542$ & 0,0001 & $0,00005^{* *}$ \\
\hline LNDAK & - & $-0,245885$ & 0,135193 & $-1,818773$ & 0,0718 & $0,0359^{* *}$ \\
\hline LNDOK & - & $-0,070780$ & 0,592085 & $-0,119544$ & 0,9051 & $0,45255^{* *}$ \\
\hline LNBM & - & $-0,023270$ & 0,161514 & $-0,144077$ & 0,8857 & $0,44285^{* *}$ \\
\hline LNPDRB & - & $-1,648222$ & 0,695915 & $-2,765866$ & 0,0067 & $0,00335^{* *}$ \\
\hline Adjusted R R $^{2}: 0,998812$ & & & Prob F: 0,0000 \\
\hline
\end{tabular}

Keterangan: tanda $* *$ menunjukkan tingkat signifikansi 0,05

Keputusan: nilai probabilitas $<0,05$ atau nilai $\mathrm{t}$ tabel $(1,65)<\mathrm{t}$ hitung, maka signifikan

Sumber: diolah dari output Eviews (2021)

Nilai adjusted R2 dalam model persamaan II sebesar 0,998812, artinya variabel PAD, DAU, DAK, Dana Otonomi Khusus, belanja modal, dan PDRB dapat menjelaskan variabel kemiskinan sebesar 99,88 persen. Selisihnya sebesar 0,12 persen dijelaskan oleh variabel lain di luar model persamaan II. Hasil uji F model persamaan II menunjukkan nilai probabilitas lebih kecil dari 0,05 yaitu sebesar 0,0000. Hal ini diinterpretasikan bahwa variabel PAD, DAU, DAK, Dana Otonomi Khusus, belanja modal, dan PDRB secara simultan mempunyai pengaruh signifikan terhadap kemiskinan. Berdasarkan nilai probailitas dan uji t, hasil penelitian menunjukkan bahwa PAD, Dana Otonomi Khusus, belanja modal tidak berpengaruh signifikan terhadap kemiskinan. Sementara itu, DAU, DAK, dan PDRB berpengaruh negatif signifikan terhadap kemiskinan.

\section{Hasil Analisis Jalur}

Gambar 4. Hasil Analisis Jalur

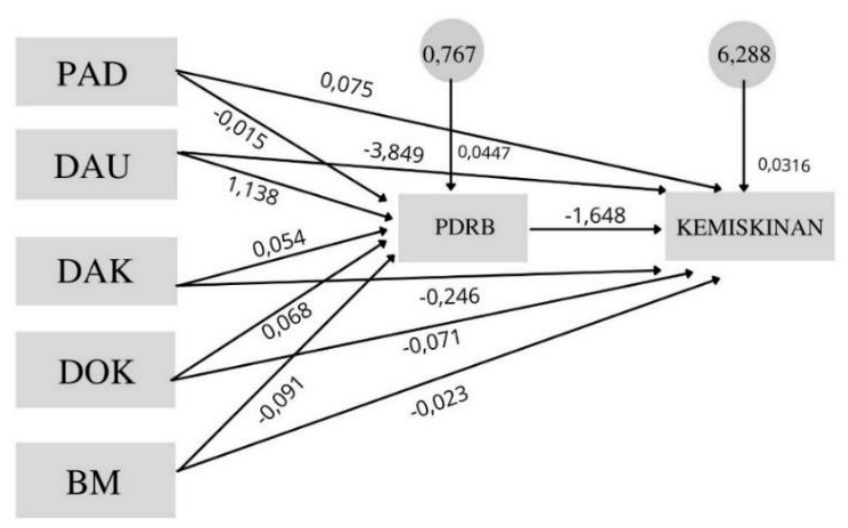

Sumber: diolah penulis (2021) 


\section{JURNALKU}

Volume 1 No. 3, September 2021

\section{Hasil Uji Sobel}

Tabel 6. Hasil Uji Sobel

\begin{tabular}{lccc}
\hline $\begin{array}{l}\text { Variabel } \\
\text { Independen }\end{array}$ & $\begin{array}{c}\text { Pengaruh tidak langsung } \\
\text { (koef. variabel } \\
\text { independen terhadap } \\
\text { PDRB x koef. PDRB } \\
\text { terhadap kemiskinan) }\end{array}$ & $\begin{array}{c}\text { Standar error } \\
\text { pengaruh tidak } \\
\text { langsung }\end{array}$ & $\begin{array}{c}\text { Hasil Uji Sobel } \\
\text { (pengaruh tidak } \\
\text { langsung : standar error } \\
\text { pengaruh tidak } \\
\text { langsung) }\end{array}$ \\
\hline PAD & 0,025420528 & 0,016324835 & 1,557169059 \\
\hline DAU & $-1,875927166$ & 0,7007966 & $-2,67685$ \\
\hline DAK & $-0,088664454$ & 0,04784329 & $-1,8532263$ \\
\hline DOK & $-0,11243676$ & 0,13040459 & $-0,8622147$ \\
\hline BM & 0,150096985 & 0,07064308 & 2,12472317 \\
\hline
\end{tabular}

Sumber: diolah penulis (2021)

Uji sobel dilakukan untuk mengetahui signifikansi pengaruh tidak langsung variabel independen terhadap variabel dependen melalui variabel mediasi. Uji sobel dilakukan dengan membandingkan nilai t hitung dengan $t$ tabel $(1,65)$. Hasilnya adalah pengaruh variabel independen terhadap kemiskinan melalui pertumbuhan ekonomi yakni DAU dan DAK berpengaruh negatif; belanja modal berpengaruh positif signifikan; PAD dan Dana Otonomi Khusus tidak berpengaruh signifikan.

\section{Pembahasan}

\section{Pengaruh PAD terhadap Pertumbuhan Ekonomi}

Berdasarkan pengujian hipotesis, PAD berpengaruh negatif signifikan terhadap pertumbuhan ekonomi. Hasil penelitian ini tidak sesuai dengan teori federalisme fiskal dan Keynes serta tidak sejalan dengan penelitian Jolianis (2016). Namun, penelitian ini sejalan dengan penelitian Suwandika dan Yasa (2015) dan Dewi dan Suputra (2017). PAD berpengaruh negatif terhadap pertumbuhan ekonomi disebabkan biaya dalam menghasilkan PAD lebih besar dari manfaatnya. Hal ini ditunjukkan dalam LHP atas LKPD beberapa kabupaten. Kabupaten Kepulauan Yapen 2017 melakukan pembayaran insentif pajak dan retribusi yang seharusnya tidak dibayarkan. Seharusnya pembayaran insentif dilakukan ketika instansi pemungut mencapai target penerimaan dalam triwulan tersebut. Kabupaten Yalimo 2017 dan Merauke 2018 juga menyatakan bahwa belanja insentif pemungutan retribusi daerah pada pelaksana pemungutan retribusi daerah melebihi yang seharusnya.

Berdasarkan analisis data yang dilakukan, nilai PAD kabupaten/kota di Provinsi Papua terjadi ketimpangan cukup besar. Akibatnya, output yang didanai menggunakan PAD baik dari segi kuantitas maupun kualitas antarkabupaten/kota di Provinsi Papua terjadi ketimpangan. Besaran PAD selama ini juga relatif kecil sehingga belum dapat berperan dalam kegiatan pembangunan. Rendahnya PAD yang diterima dapat disebabkan oleh beberapa permasalahan dalam pengelolaan PAD yang diungkapkan dalam LHP kabupaten kota di Provinsi Papua, seperti peraturan daerah tentang besaran dan mekanisme pemungutan pajak dan retribusi daerah yang belum diatur; pendataan Wajib Pajak/Wajib Retribusi tidak memadai; keterlambatan penyetoran. Hal-hal yang belum jelas diatur dalam peraturan akan menimbulkan keraguan dalam pelaksanaan pemungutan sehingga memberikan dampak yang berbeda terhadap perekonomian (Juliarini, 2020). Selain itu, pemerintah daerah berpotensi kehilangan pendapatan yang akan berdampak pada belanja untuk meningkatkan pertumbuhan ekonomi serta pemerintah daerah tidak dapat segera 


\section{JURNALKU}

Volume 1 No. 3, September 2021

memanfaatkan PAD untuk pendanaan belanja dan terdapat peluang penyalahgunaan atas penerimaan yang tidak disetor 1 x 24 jam.

\section{Pengaruh DAU terhadap Pertumbuhan Ekonomi}

Berdasarkan pengujian hipotesis, DAU berpengaruh signifikan dan memberikan pengaruh positif terhadap pertumbuhan ekonomi. Nilai koefisien DAU sebesar 1,14, artinya setiap kenaikan DAU satu persen dapat meningkatkan pertumbuhan ekonomi yang diproksikan dengan PDRB sebesar 1,14 persen. Hasil penelitian ini sejalan dengan teori federalisme fiskal, teori Keynes. Penelitian ini juga sejalan dengan penelitian Gunantara dan Dwirandra (2014), dan Jolianis (2016). DAU berpengaruh positif signifikan karena perhitungan besaran DAU setiap kabupaten/kota mempertimbangkan banyak aspek sesuai dengan kondisi dan kemampuan daerahnya serta DAU yang bersifat block grant dengan jumlah alokasi yang cukup besar membuat pemerintah daerah lebih fleksibel dalam mengalokasikan belanja yang bersumber dari DAU. Pemerintah daerah dapat mengalokasikan belanja untuk meningkatkan layanan penduduk sehingga tercipta kegiatan perekonomian yang dapat meningkatkan output barang dan jasa yang diproduksi sehingga pertumbuhan ekonomi meningkat. Dalam LKPD Kabupaten Mappi 2018, alokasi DAU digunakan untuk bantuan usaha kepada mama-mama Papua. LKPD Kabupaten Sarmi tahun 2018 juga menunjukkan DAU digunakan untuk mendanai bantuan modal usaha bagi industri kecil dan menengah dalam bentuk pelatihan, pendampingan, dan bantuan peralatan. Bentuk bantuan berupa pelatihan dan pendampingan dapat meningkatkan keterampilan penduduk sehingga produktivitas penduduk dapat meningkat dan output barang dan jasa yang diproduksi semakin banyak. Bantuan peralatan dapat memperlancar proses produksi yang akan berdampak terhadap kuantitas dan kualitas barang yang diproduksi.

\section{Pengaruh DAK terhadap Pertumbuhan Ekonomi}

Berdasarkan pengujian hipotesis, DAK berpengaruh signifikan dan memberikan pengaruh positif terhadap pertumbuhan ekonomi. Nilai koefisien DAK sebesar 0,053794, artinya setiap kenaikan DAK satu persen dapat meningkatkan pertumbuhan ekonomi yang diproksikan dengan PDRB sebesar 0,053794 persen. Hasil penelitian ini sejalan dengan teori federalisme fiskal dan teori Keynes. Penelitian ini sejalan dengan penelitian Kusumawati dan Wiksuana (2018) dan Susanto dan Marhamah (2016). Alokasi DAK dapat meningkatkan pertumbuhan ekonomi disebabkan cakupan bidang yang didanai DAK cukup banyak dan adanya perubahan kebijakan pengalokasian DAK pada tahun 2016. Perubahan kebijakan DAK pada tahun 2016 antara lain pengalokasian DAK berdasarkan proposal yang diajukan pemerintah daerah mengenai kebutuhan daerahnya; penghapusan kewajiban dana pendamping; penetapan juknis dengan Perpres yang berlaku selama tiga tahun; penyaluran dilakukan secara triwulan per bidang; penyaluran berbasis kinerja penyerapan; pelaporan wajib menyampaikan capaian output/outcome dan menyempurnakan pelaporan berbasis sistem aplikasi (Direktorat Jenderal Perimbangan Keuangan, 2017). Dengan mengajukan proposal sesuai kebutuhan daerah, alokasi DAK akan lebih efisien dan efektif. Kewajiban menyampaikan capaian output/outcome juga mendorong pemerintah daerah menggunakan DAK seoptimal mungkin.

\section{Pengaruh Dana Otonomi Khusus terhadap Pertumbuhan Ekonomi}

Berdasarkan pengujian hipotesis, Dana Otonomi Khusus tidak berpengaruh signifikan terhadap pertumbuhan ekonomi. Hasil penelitian ini berbeda dengan penelitian Anwar et al. (2018). Namun, penelitian ini sejalan dengan penelitian Mediyanti (2019) yang menyatakan bahwa Dana Otonomi Khusus tidak berpengaruh terhadap pertumbuhan ekonomi di Provinsi Aceh karena alokasi belanja yang bersumber dari Dana Otonomi Khusus tidak difokuskan pada sektor-sektor perekonomian. 


\section{JURNALKU}

Volume 1 No. 3, September 2021

Badan Pemeriksa Keuangan (2021) menyatakan terdapat permasalahan pelaporan seperti laporan realisasi tidak dibuat secara berkala, terlambat, dan/atau tidak akurat karena belum seluruhnya mencantumkan output kegiatan dan menjelaskan penggunaan sisa dana pada periode sebelumnya. Akibatnya, laporan tidak dapat diandalkan, tidak dapat digunakan sebagai dasar pertimbangan dalam mengalokasikan pembagian Dana Otonomi Khusus di tahun berikutnya, dan dapat menghambat pencairan Dana Otonomi Khusus di tahap berikutnya. Selain itu, terdapat 361 permasalahan pengelolaan Dana Otonomi Khusus dalam hasil pemeriksaan BPK tahun 2008-2019 seperti kekurangan volume, belanja perjalanan dinas/pengadaan fiktif, keterlambatan penyelesaian pekerjaan, ketidaksesuaian spesifikasi teknis, dan pertanggungjawaban yang tidak lengkap. Hal ini akan mempengaruhi efektivitas pencapaian Dana Otonomi Khusus.

Berdasarkan hasil analisis data, jumlah Dana Otonomi Khusus yang diterima dari pusat selalu meningkat, tetapi jumlah tiap kabupaten/kota untuk setiap tahunnya tidak mengalami peningkatan dan cenderung sama. Selain itu, penggunaan Dana Otonomi Khusus ada yang diatur oleh pemerintah pusat dan ada yang diserahkan kepada pemerintah daerah. Hal tersebut dapat menimbulkan unsur politik baik dalam pengalokasian anggaran ke kabupaten/kota maupun penggunaan anggarannya sehingga pengelolaan Dana Otonomi Khusus tidak optimal. Aziz, et al. (2018) menyatakan bahwa Dana Otonomi Khusus hanya dimanfaatkan oleh elite politik di daerah untuk memenuhi kepentingan pribadi dan pengawasan yang kurang optimal baik dari pemerintah pusat maupun daerah menyebabkan elite politik semakin leluasa menjalankan aksinya. Salah satu penyebab pemeriksaan yang kurang optimal adalah keadaan geografis yang cukup sulit. Pemeriksa harus menempuh daerah dengan jangkauan yang luas dan menyiapkan biaya transportasi yang lebih besar. Hal ini berpeluang Dana Otonomi Khusus tidak dimanfaatkan untuk kepentingan penduduk. Pengaruh Belanja Modal terhadap Pertumbuhan Ekonomi

Berdasarkan pengujian hipotesis, belanja modal berpengaruh negatif signifikan terhadap pertumbuhan ekonomi. Hasil penelitian ini sejalan dengan penelitian Gunantara dan Dwirandra (2014). Belanja modal berpengaruh negatif terhadap pertumbuhan ekonomi dapat disebabkan oleh beberapa hal. Pertama, manfaat belanja modal tidak dapat dirasakan pada tahun anggaran yang sama. Menurut Syadullah dan Setyawan (2020), belanja modal pemerintah seperti jalan dan irigasi mulai menunjukkan dampak positif terhadap pertumbuhan ekonomi pada tahun keempat, sedangkan tahun pertama dan kedua masih menunjukkan dampak negatif. Kedua, permasalahan dalam pengelolaan belanja modal yang diungkapkan dalam LHP atas LKPD kabupaten/kota seperti kekurangan volume pekerjaan, keterlambatan penyelesaian pekerjaan, ketidaksesuaian peruntukannya, dan kualitas infrastruktur yang rendah. Salah satu rendahnya kualitas infrastruktur diungkapkan dalam RKPD Provinsi Papua 2018 yaitu persentase kenaikan jalan yang rusak lebih cepat dibandingkan penambahan pembangunan jalan. Berbagai permasalahan tersebut mengakibatkan pekerjaan yang dilakukan tidak dapat segera dimanfaatkan, distribusi barang dan jasa terhambat, mobilitas penduduk terhambat, kegiatan perekonomian terhambat, dan terdapat kelebihan pembayaran yang menyebabkan belanja modal menjadi tidak efisien dan efektif.

\section{Pengaruh PAD terhadap Kemiskinan}

Berdasarkan pengujian hipotesis, PAD tidak berpengaruh signifikan terhadap kemiskinan. Hasil penelitian ini tidak sejalan dengan penelitian Jolianis (2016). Namun, hasil penelitian ini sejalan dengan penelitian Siregar dan Ramadhan (2020), Kadafi dan Murtala (2020). PAD tidak berpengaruh signifikan disebabkan oleh oleh biaya dalam menghasilkan PAD lebih besar dari manfaatnya. Menurut Sidik (2002a), biaya yang lebih besar itu disebabkan oleh perbedaan jumlah penduduk, keadaan geografis, dan kemampuan masyarakat. Selain itu, Siregar dan Ramadhan (2020) menyatakan bahwa PAD tidak berpengaruh signifikan karena pengelolaan PAD belum tepat 


\section{JURNALKU}

Volume 1 No. 3, September 2021

sasaran. Hal ini sejalan dengan adanya permasalahan dalam pengelolaan PAD yang menyebabkan potensi pendapatan daerah menjadi rendah dan tidak optimal. Berdasarkan analisis data, PAD yang dihasilkan kabupaten/kota di Provinsi Papua mayoritas masih rendah. Terbatasnya jumlah PAD yang dimiliki suatu daerah dapat membatasi ruang gerak pemerintah daerah untuk mengalokasikan belanja yang berujung pada kesejahteraan penduduk seperti program-program kemiskinan.

\section{Pengaruh DAU terhadap Kemiskinan}

Berdasarkan pengujian hipotesis, DAU berpengaruh negatif signifikan terhadap tingkat kemiskinan. Pengaruh langsung DAU terhadap kemiskinan bernilai -3,85 dan signifikan. Ketika DAU naik satu persen, kemiskinan akan berkurang 3,85 persen. Penelitian ini sejalan dengan penelitian Jolianis (2016), Kadafi dan Murtala (2020). DAU yang bersifat block grant dan jumlah DAU yang cukup besar mampu digunakan oleh pemerintah daerah untuk mendanai programprogram kemiskinan. Penggunaan DAU untuk memenuhi kebutuhan penduduk miskin ditujukan dalam beberapa LKPD Kabupaten. LKPD Kabupaten Merauke 2015 menunjukkan bahwa DAU digunakan untuk mendanai stimulasi pembangunan perumahan bagi penduduk miskin. Hal ini sesuai dengan penyebab kemiskinan di Papua berupa tempat tinggal yang tidak layak huni. LKPD Kabupaten Deiyai 2015 menunjukkan bahwa DAU digunakan untuk mendanai bantuan modal usaha berupa uang tunai. Dalam LKPD Kabupaten Puncak 2017 dan Lanny Jaya 2018, DAU digunakan untuk belanja bantuan sosial dan bantuan tunai kepada penduduk miskin. Selain itu, sejalan dengan penyebab kemiskinan di Provinsi Papua berupa kurangnya kemudahan akses penduduk miskin untuk memperoleh pendidikan, DAU digunakan untuk mendanai pengadaan bus sekolah pada LKPD Kabupaten Mappi 2017 dan belanja bantuan sosial kepada pelajar SD, SLTP, SLTA dan mahasiswa pada LKPD Kabupaten Asmat 2016 dan 2017.

\section{Pengaruh DAK terhadap Kemiskinan}

Berdasarkan pengujian hipotesis, DAK berpengaruh negatif signifikan terhadap kemiskinan. Pengaruh langsung DAK terhadap kemiskinan bernilai 0,25. Ketika DAK naik satu persen, kemiskinan akan berkurang 0,25 persen. Hasil penelitian ini sejalan dengan penelitian Qomariyah, et al. (2016), Fitriyanti dan Handayani (2020). DAK berpengaruh signifikan dapat disebabkan oleh pengajuan proposal dari pemerintah daerah sudah tertuju untuk mendanai program-program prioritas nasional yang menjadi wewenang daerah, salah satunya fokus untuk mendanai program-program kemiskinan. Selain itu, cakupan bidang yang didanai DAK cukup banyak sehingga dapat dirasakan manfaatnya oleh penduduk miskin, seperti bidang pendidikan, kesehatan, pertanian, kelautan dan perikanan, perumahan dan permukiman, infrastruktur sanitasi, infrastruktur air minum, lingkungan hidup, kehutanan, dan perdagangan. Berbagai bidang tersebut sejalan dengan penyebab kemiskinan di Provinsi Papua, antara lain alokasi di bidang Pendidikan seperti DAK tunjangan khusus guru, DAK tambahan penghasilan guru dapat mempertahankan kehadiran guru. Hal ini sejalan dengan salah satu penyebab kemiskinan di Provinsi Papua yaitu kurangnya tenaga pengajar. Selain itu, alokasi di bidang pertanian dapat mengurangi kemiskinan karena penduduk miskin lebih banyak berada di pedesaan dan bekerja di sektor pertanian.

\section{Pengaruh Dana Otonomi Khusus terhadap Kemiskinan}

Berdasarkan pengujian hipotesis, Dana Otonomi Khusus tidak berpengaruh signifikan terhadap kemiskinan. Penelitian ini sejalan dengan hasil penelitian Kadafi dan Murtala (2020). Menurut Kadafi dan Murtala (2020), Dana Otonomi Khusus tidak berpengaruh terhadap kemiskinan karena penyaluran dan penggunaan Dana Otonomi Khusus belum tepat sasaran dan tidak efektif. Dana Otonomi Khusus tidak berpengaruh signifikan dapat disebabkan oleh permasalahan dalam pengelolaannya seperti kekurangan volume pekerjaan dan keterlambatan pekerjaan seperti pengadaan obat-obatan dan alat-alat kesehatan. Kekurangan volume pengadaan 


\section{JURNALKU}

Volume 1 No. 3, September 2021

alat-alat kesehatan menyebabkan kualitas kesehatan di Provinsi Papua menjadi tetap rendah dan tidak mampu menurunkan kemiskinan secara signifikan. Selain itu, penggunaan dana yang diberikan kepada pihak yang tidak berhak dan penggunaan dana yang tidak ada bukti pertanggungjawaban dapat mengindikasikan penggunaan Dana Otonomi Khusus tidak digunakan sesuai tujuan atau dapat disalahgunakan. Adanya unsur politik dalam pengelolaan Dana Otonomi Khusus juga menjadi penyebab Dana Otonomi Khusus tidak berpengaruh signifikan terhadap penurunan kemiskinan. Hal ini disebabkan dana yang ada tidak digunakan untuk memenuhi kepentingan penduduk tetapi digunakan untuk memenuhi kepentingan pribadi atau kelompok politik tertentu.

\section{Pengaruh Belanja Modal terhadap Kemiskinan}

Berdasarkan pengujian hipotesis, belanja modal tidak berpengaruh signifikan terhadap kemiskinan. Hasil penelitian ini sejalan dengan hasil penelitian Widianto et al. (2016), Putro et al. (2017). Menurut Putro et al. (2017), belanja modal tidak berpengaruh signifikan karena pembangunan infrastruktur tidak melibatkan penduduk miskin secara langsung. Proyek infrastruktur yang kurang melibatkan tenaga kerja lokal juga terjadi di Provinsi Papua. Kepala Kampung Musaima di Kabupaten Jayawijaya yaitu Ibrahim Huda menyatakan bahwa orang Papua belum mengetahui cara membuat rumah atap kering, jembatan, dan jalan sehingga tukang selama ini berasal dari Toraja, Makassar, atau Jawa (BBC News Indonesia, 2018). Selain itu, permasalahan dalam pengelolaan belanja modal seperti kekurangan volume pekerjaan, keterlambatan penyelesaian pekerjaan, kelebihan pembayaran, dan kesalahan dalam peruntukannya mengakibatkan manfaat dari penggunaan dana tidak dapat dirasakan penduduk miskin secara optimal.

\section{Pengaruh Pertumbuhan Ekonomi terhadap Kemiskinan}

Hasil regresi data panel menunjukkan bahwa PDRB berpengaruh negatif signifikan terhadap tingkat kemiskinan. Ketika PDRB naik satu persen, tingkat kemiskinan akan turun sebesar 1,65 persen. Hasil penelitian ini sejalan dengan penelitian Sudewi dan Wirathi (2013), Jolianis (2016). Pertumbuhan ekonomi yang dicapai Provinsi Papua menunjukkan kemampuan pemerintah daerah dalam mengoptimalkan sektor-sektor ekonomi yang dapat menyediakan lapangan pekerjaan dan meningkatkan pendapatan bagi penduduk miskin. Tingginya produksi barang dan jasa ini akan meningkatkan permintaan tenaga kerja dan berdampak terhadap pendapatan yang diterima oleh penduduk miskin.

\section{Pengaruh PAD terhadap Kemiskinan melalui Pertumbuhan Ekonomi}

Hasil regresi panel menunjukkan bahwa PAD tidak berpengaruh signifikan terhadap kemiskinan melalui pertumbuhan ekonomi. Hasil penelitian ini tidak sejalan dengan penelitian Jolianis (2016), tetapi sejalan dengan penelitian Nurhidayah dan Hendikawati (2018). Berdasarkan hasil penelitian, pengaruh PAD terhadap pertumbuhan ekonomi negatif signifikan. Hal ini mengindikasikan bahwa peningkatan PAD gagal meningkatkan pertumbuhan ekonomi. Ketika pemerintah gagal meningkatkan pertumbuhan ekonomi yang berkualitas, penurunan kemiskinan menjadi terhambat karena kurangnya lapangan pekerjaan, tidak meratanya pendapatan, dan terbatasnya akses faktor produksi untuk penduduk miskin. Selain itu, PAD tidak berpengaruh dapat disebabkan biaya yang lebih besar daripada manfaat dalam menghasilkan PAD, salah satunya ditunjukkan pada belanja pegawai di Provinsi Papua. Menurut Sidik (2002a), permasalahan dalam pemanfaatan PAD termasuk kemampuan administrasi pemungutan pajak disebabkan adanya perbedaan jumlah penduduk dan kemampuan masyarakat yang mengakibatkan biaya pungut dan biaya pelayanan kepada masyarakat menjadi lebih besar. 


\section{JURNALKU}

Volume 1 No. 3, September 2021

\section{Pengaruh DAU terhadap Kemiskinan melalui Pertumbuhan Ekonomi}

Hasil regresi panel menunjukkan bahwa pengaruh DAU terhadap kemiskinan melalui pertumbuhan ekonomi adalah negatif signifikan. Pengaruh tidak langsung DAU terhadap kemiskinan melalui pertumbuhan ekonomi bernilai -1,88, artinya peningkatan DAU satu persen dapat menurunkan kemiskinan melalui pertumbuhan ekonomi sebesar 1,88 persen. Penelitian ini sejalan dengan penelitian Jolianis (2016). DAU dapat mengurangi kemiskinan melalui pertumbuhan ekonomi menunjukkan pemanfaatan DAU untuk belanja dapat meningkatkan produksi barang dan jasa sesuai teori Keynes. Akibatnya, permintaan tenaga kerja meningkat dan penduduk dapat bekerja untuk meningkatkan pendapatannya, termasuk penduduk miskin. dan signifikan.

\section{Pengaruh DAK terhadap Kemiskinan melalui Pertumbuhan Ekonomi}

Berdasarkan pengujian hipotesis, pengaruh DAK terhadap kemiskinan melalui pertumbuhan ekonomi adalah negatif signifikan. Pengaruh tidak langsung DAK terhadap kemiskinan melalui pertumbuhan ekonomi bernilai -0,089, artinya peningkatan DAK satu persen dapat menurunkan kemiskinan melalui pertumbuhan ekonomi sebesar 0,089 persen. Hal ini dapat disebabkan oleh pemanfaatan DAK di berbagai bidang. Salah satunya ditunjukkan pada penggunaan DAK untuk mendanai bidang pertanian, kehutanan, kelautan dan perikanan. Jumlah penduduk berumur 15 tahun ke atas pada tahun 2018 di Provinsi Papua menunjukkan 67,75 persen penduduk bekerja di sektor pertanian, kehutanan, perburuan, dan perikanan (Badan Pusat Statistik Provinsi Papua, 2019b). Penggunaan DAK untuk mendanai bidang pertanian, kehutanan, kelautan dan perikanan dapat meningkatkan produktivitas penduduk yang bekerja di sektor tersebut. Akibatnya, pendapatan penduduk meningkat, mampu menciptakan multiplier effect, dan mempunyai dampak terhadap pendapatan penduduk miskin untuk memenuhi kebutuhan dasarnya. Pengaruh Dana Otonomi Khusus terhadap Kemiskinan melalui Pertumbuhan Ekonomi

Berdasarkan pengujian hipotesis, Dana Otonomi Khusus tidak berpengaruh signifikan terhadap kemiskinan melalui pertumbuhan ekonomi. Hal ini dapat disebabkan oleh permasalahan tata kelola Dana Otonomi Khusus dan faktor lainnya seperti keadaan geografis dan sumber daya manusia yang ada. Akibatnya, pemanfaatan Dana Otonomi Khusus belum optimal. Hal ini ditunjukkan pada indikator pendidikan dan kesehatan di Provinsi Papua yang masih relatif rendah. Provinsi Papua mempunyai rata-rata lama sekolah paling rendah di Indonesia. Pada tahun 2018, rata-rata lama sekolah Provinsi Papua sebesar 6,52 tahun. Dalam lingkup regional, 16 dari 28 kabupaten/kota di Provinsi Papua mempunyai rata-rata lama sekolah lebih rendah dari Provinsi Papua (Badan Pusat Statistik, n.d.-e). Kabupaten Puncak merupakan wilayah dengan rata-rata lama sekolah terendah yaitu 1,95 tahun. Provinsi Papua juga merupakan provinsi dengan Angka Harapan Hidup terendah ketiga di Indonesia (Badan Pusat Statistik, n.d.-a). Rendahnya pendidikan dan kesehatan akan mempengaruhi kemampuan manusia dalam melakukan aktivitas ekonomi. Akibatnya, kegiatan ekonomi yang berasal dari pemanfaatan Dana Otonomi Khusus hanya melibatkan kelompok tertentu dan belum berdampak terhadap penduduk miskin.

Pengaruh Belanja Modal terhadap Kemiskinan melalui Pertumbuhan Ekonomi

Berdasarkan pengujian hipotesis, pengaruh belanja modal terhadap tingkat kemiskinan melalui pertumbuhan ekonomi yaitu positif signifikan. Pengaruh tidak langsung belanja modal terhadap kemiskinan menunjukkan nilai positif yaitu sebesar 0,15. Artinya, kenaikan belanja modal satu persen dapat meningkatkan kemiskinan melalui pertumbuhan ekonomi sebesar 0,15 persen. Hal ini dapat disebabkan oleh beberapa faktor. Pertama adalah manfaat belanja modal yang tidak dapat dirasakan pada tahun yang sama. Kedua adalah rendahnya kualitas belanja modal yang menyebabkan biaya yang dikeluarkan lebih besar dari manfaatnya. Hal ini ditunjukkan lebih dari 


\section{JURNALKU}

Volume 1 No. 3, September 2021

50 persen panjang jalan di Provinsi Papua dalam kondisi rusak pada tahun 2016 (Badan Pusat Statistik Provinsi Papua, 2019b). Kerusakan jalan dapat menghambat proses distribusi dan menghambat mobilitas penduduk untuk menuju pusat perekonomian. Ketiga adalah rendahnya tingkat utilitas barang publik yang menghasilkan manfaat lebih kecil dari pengeluarannya. Hal ini ditunjukkan Angka Partisipasi Sekolah penduduk usia 16-18 tahun relatif rendah yaitu terdapat 37,81 persen penduduk yang tidak bersekolah pada tahun 2018. Akibatnya, daya serap penduduk usia sekolah dalam memanfaatkan fasilitas pendidikan masih rendah. Tingkat utilitas layanan publik yang rendah juga ditunjukkan dalam bidang kesehatan. Badan Pusat Statistik Provinsi Papua (2019a) menyatakan bahwa mengobati sendiri masih menjadi alasan utama penduduk di Provinsi Papua tidak berobat jalan hingga tahun 2018. Akibatnya, pemanfaatan fasilitas kesehatan masih rendah. Persentase penduduk yang berobat jalan menurut daerah tempat tinggal dan tempat berobat Provinsi Papua pada tahun 2018 secara rata-rata sebesar 13,05 persen (Badan Pusat Statistik Provinsi Papua, 2019a).

\section{PENUTUP}

\section{Simpulan}

Berdasarkan uraian sebelumnya, simpulan dalam penelitian ini adalah DAU dan DAK berpengaruh positif signifikan terhadap pertumbuhan ekonomi; Dana Otonomi Khusus tidak berpengaruh signifikan terhadap pertumbuhan ekonomi; PAD dan belanja modal berpengaruh negatif signifikan terhadap pertumbuhan ekonomi; DAU, DAK, dan pertumbuhan ekonomi berpengaruh negatif signifikan terhadap kemiskinan; Dana Otonomi Khusus dan belanja modal tidak berpengaruh signifikan terhadap kemiskinan; PAD tidak berpengaruh signifikan terhadap kemiskinan; DAU dan DAK berpengaruh negatif signifikan terhadap kemiskinan melalui pertumbuhan ekonomi; PAD dan Dana Otonomi Khusus tidak berpengaruh signifikan terhadap kemiskinan melalui pertumbuhan ekonomi; belanja modal berpengaruh positif dan signifikan terhadap kemiskinan melalui pertumbuhan ekonomi.

\section{Saran}

Keterbatasan penelitian ini yaitu tidak menguraikan tiap-tiap bidang DAK, komponen belanja modal, dan belum memperhatikan jens belanja pemerintah yang lain.; tidak memperhitungkan jeda waktu antara pengaruh belanja modal terhadap pertumbuhan ekonomi; tidak mengeluarkan outlier. Saran dalam penelitian ini yaitu pemerintah daerah dapat mempertahankan dan meningkatkan pemanfaatan DAU dan DAK, serta melakukan evaluasi terhadap pengelolaan PAD, Dana Otonomi Khusus, dan belanja modal. Penelitian selanjutnya dapat menguraikan bidang-bidang DAK, komponen belanja modal, dan belanja pemerintah yang lain.

\section{DAFTAR PUSTAKA}

Anwar, A. R. D., Abdullah, M. F., \& Hadi, S. (2018). Analisis Pengaruh Pendapatan Asli Daerah, Dana Otonomi Khusus dan Belanja Modal Terhadap PDRB di Kab/Kota Provinsi Papua. Jurnal Ilmu Ekonomi, 2(1), 1-13.

Aziz, N. L. L., Zuhro, R. S., Cahyono, H., Suryani, D., Aulia, D., \& Maulana, Y. (2018). Pola Pengawasan Pengelolaan Dana Otonomi Khusus dan Istimewa: Perspektif Politik. Jurnal Penelitian Politik, 15(726), 81-96.

Badan Pemeriksa Keuangan. (2021). Pendapat BPK dalam Pengelolaan Dana Otonomi Khusus pada Provinsi Papua dan Papua Barat 2021.

Bahl, R. (2008). The Pillars of Fiscal Decentralization. CAF Working Papers. 


\section{http://scioteca.caf.com/handle/123456789/257}

Dewi, N. W. R., \& Suputra, I. D. G. D. (2017). Pengaruh Pendapatan Asli Daerah, Dana Alokasi Umum, Dana Alokasi Khusus, dan Belanja Modal terhadap Pertumbuhan Ekonomi. E-Jurnal Akuntansi Universitas Udayana, 1(1), 1745-1773.

Eviews. (2017). Eviews 10 User's Guide II. IHS Global Inc.

Fitriyanti, N. I., \& Handayani, H. R. (2020). Pengaruh Pendapatan Asli Daerah (PAD), Dana Alokasi Khusus (DAK), dan Belanja Daerah terhadap Tingkat Kemiskinan (Studi Kasus 35 Kabupaten/Kota di Provinsi Jawa Tengah Tahun 2012-2016). Diponegoro Journal of Economics, 9, 79-90.

Gujarati, D. N. (2004). Basic Econometrics Fourt (4th ed.). McGrow-Hills Companies.

Gunantara, P. C., \& Dwirandra, A. A. N. B. (2014). Pengaruh Pendapatan Asli Daerah dan Dana Alokasi Umum pada Pertumbuhan Ekonomi dengan Belanja Modal sebagai Variabel Pemoderasi di Bali. E-Jurnal Akuntansi Universitas Udayana, 3, 529-546.

Jolianis. (2016). Analisis Pengaruh PAD, DAU, dan DAK terhadap Kemiskinan pada Kabupaten/Kota di Provinsi Sumatera Barat dengan Pertumbuhan Ekonomi sebagai Variabel Intervening. Economica, 4(2), 192-209. https://doi.org/10.22202/economica.2016.v4.i2.633

Juliarini, A. (2020). Komparasi Penerimaan Pajak Daerah Kota dan Kabupaten di Indonesia Setelah Berlakunya Undang-Undang Pajak Daerah dan Retribusi Daerah. Jurnal BPPK: Badan Pendidikan Dan Pelatihan Keuangan, 13(2), 1-10. https://doi.org/10.48108/jurnalbppk.v13i2.227

Kadafi, M., \& Murtala. (2020). Pengaruh Pendapatan Asli Daerah, Dana Alokasi Umum, dan Dana Otonomi Khusus terhadap Tingkat Kemiskinan di Provinsi Aceh Periode 2010-2017. Jurnal Ekonomi Regional Unimal, $3(2), \quad$ 23-31. https://doi.org/https://doi.org/10.29103/jeru.v3i2.3203

Kadji, Y. (2012). Kemiskinan dan Konsep Teoritisnya. Fakultas Ekonomi Dan Bisnis UNG.

Kementerian Keuangan. (2020). Nota Keuangan beserta Anggaran Pendapatan dan Belanja Negara Tahun 2020.

Kementerian PPN/Bappenas. (2018). Analisis Wilayah dengan Kemiskinan Tinggi. Kedeputian Bidang Kependudukan Dan Ketenagakerjaan Kementerian PPN/Bappenas, 10.

Kusumawati, L., \& Wiksuana, I. G. B. (2018). Pengaruh Pendapatan Daerah terhadap Pertumbuhan Ekonomi di Wilayah Sarbagita Provinsi Bali. E-Jurnal Manajemen Universitas Udayana, 7(5), 2592. https://doi.org/10.24843/ejmunud.2018.v07.i05.p12

Kuznets, S. (1973). Modern Economic Growth : Findings and Reflections. American Economic Association, 63(3), 247-258.

Mankiw, N. G. (2016). Macroeconomics (9th ed.). Worth Publishers.

Mediyanti, S. (2019). Analisis Dampak Penggunaan Dana Otonomi Khusus Aceh (DOKA) terhadap Pertumbuhan Ekonomi Provinsi Aceh. Jurnal Ilmu Manajemen, 7(1), 56-60.

Muliadi, M., \& Amri, K. (2019). Penerimaan Zakat dan Penurunan Kemiskinan di Aceh: Peran Dana Otonomi Khusus sebagai Pemoderasi. Jurnal Ilmiah Ekonomi Islam, 5(3), 231-244.

Nurhidayah, T., \& Hendikawati, P. (2018). Pengaruh Realisasi APBD Terhadap Pertumbuhan Ekonomi dan Kemiskinan dengan Statistical Mediation Analysis. Jurnal Mipa, 41(2), 111120.

Nurkse, R. (1971). The Theory of Development and the Idea of Balanced Growth. Palgrave Macmillan, 115-128. https://doi.org/10.1007/978-1-349-15452-4_9

Nurwati, N. (2008). Kemiskinan: Model Pengukuran, Permasalahan dan Alternatif Kebijakan. Jurnal Kependudukan Padjadjaran, 10(1), 1-11. 
Oates, W. E. (1999). An Essay on Fiscal Federalism. Journal of Economic Literature, XXXVII, 1120-1149.

Putro, P. B. W., Mintarti, S., \& Wijaya, A. (2017). Analisis Determinasi Pertumbuhan Ekonomi dan Kemiskinan. Inovasi, 13(2), 121-126.

Qomariyah, N., Suharno, S., \& Priyarsono, D. S. (2016). Dampak Transfer Fiskal dan Belanja Modal Pemerintah Daerah terhadap Perekonomian Sektoral, Ketimpangan dan Kemiskinan di Indonesia. Jurnal Ekonomi Dan Kebijakan Pembangunan, 5(2), 45-67.

Safitri, H., \& Saleh, M. (2020). Pengaruh Belanja Modal, Belaja Non Modal, Penanaman Modal Asing, dan Penanaman Modal Dalam Negeri terhadap Kemiskinan Kalimantan Selatan (Effects of Capital Expenditure, Non-Capital Expenditure, Foreign Investment, and Domestic Investment on Poverty Rate . Jurnal Ilmu Ekonomi Dan Pembangunan, 3(1), 229-242.

Sepulveda, C. F., \& Martinez-Vazquez, J. (2011). The Consequences of Fiscal Decentralization on Poverty and Income Equality. Environment and Planning C: Government and Policy, 29(2), 321-343. https://doi.org/10.1068/c1033r

Sidik, M. (2002a). Optimalisasi Pajak Daerah dan Retribusi Daerah dalam Rangka Meningkatkan Kemampuan Keuangan Daerah. Acara Orasi Ilmiah, April, 1-14.

Sidik, M. (2002b). Perimbangan Keuangan Pusat dan Daerah sebagai Pelaksanaan Desentralisasi Fiskal (Antara Teori dan Aplikasinya di Indonesia). Seminar Setahun Implementasi Kebijaksanaan Otonomi Daerah Di Indonesia.

Siregar, O. K., \& Ramadhan, P. A. (2020). Pengaruh Belanja Daerah, Pendapatan Asli Daerah dan Pertumbuhan Ekonomi terhadap Kemiskinan pada Pemerintah Kabupaten dan Kota di Sumatera Utara. Jurnal Akuntansi Bisnis Dan Publik, 11(2), 1-13.

Soleh, A. (2015). Pertumbuhan Ekonomi dan Kemiskinan di Indonesia. Ekombis Review: Jurnal Ilmiah Ekonomi Dan Bisnis, 2(2), 197-209. https://doi.org/10.37676/ekombis.v2i2.15

Sudewi, N. N. A., \& Wirathi, I. G. A. P. (2013). Pengaruh Desentralisasi Fiskal dan Pertumbuhan Ekonomi terhadap Kemiskinan Provinsi Bali. E-Jurnal EP Unud, 2(3), 135-141.

Susanto, E., \& Marhamah. (2016). Pengaruh Pendapatan Asli Daerah (PAD), Dana Alokasi Umum (DAU), dan Dana Alokasi Khusus (DAK) terhadap Pertumbuhan Ekonomi Daerah dengan Belanja Daerah sebagai Variabel Moderating (Studi Empiris pada 29 Kabupaten dan 9 Kota di Jawa Timur). Jurnal STIE Semarang, 8(1), 87-105.

Suwandika, P. E., \& Yasa, I. N. M. (2015). Pengaruh Pendapatan Asli Daerah dan Investasi terhadap Pertumbuhan Ekonomi dan Tingkat Pengangguran di Provinsi Bali. E-Jurnal Ekonomi Pembangunan Universitas Udayana, 4(7), 794-810.

Syadullah, M., \& Setyawan, D. (2020). The impact of Infrastructure Spending on Economic Growth: A Case Study of Indonesia. Communications - Scientific Letters of the University of Zilina, 23(3), A184-A192. https://doi.org/10.26552/COM.C.2021.3.A184-A192

Vo, D. H. (2010). The Economics of Fiscal Decentralization. Journal of Economic Surveys, 24(4), 657-679. https://doi.org/10.1111/j.1467-6419.2009.00600.x

Widianto, A., Utami, E. U. S., \& Nurmansyah, A. L. (2016). Pengaruh Dana Alokasi Umum, Dana Alokasi Khusus, dan Belanja Modal terhadap Pertumbuhan Ekonomi dan Tingkat Kemiskinan (Studi Kasus Pada Kota Tegal). Journal Research Accounting Politeknik Tegal, 5(2), 170176. https://doi.org/http://dx.doi.org/10.30591/monex.v5i2.417

\section{Website}

Badan Pusat Statistik. (n.d.-a). Angka Harapan Hidup (AHH) Menurut Provinsi dan Jenis Kelamin (Tahun), 2018-2020. Diakses tanggal 16 Juli 2021, dari https://www.bps.go.id/indicator/40/501/1/angka-harapan-hidup-ahh-menurut-provinsi-dan- 


\section{JURNALKU}

Volume 1 No. 3, September 2021

jenis-kelamin.html

Badan Pusat Statistik. (n.d.-b). Indeks Kemahalan Konstruksi 2017-2019. Diakses tanggal 20

April 2021, dari https://www.bps.go.id/indicator/4/128/1/indeks-kemahalan-konstruksi.html

Badan Pusat Statistik. (n.d.-c). Kemiskinan dan Ketimpangan. Diakses tanggal 24 April 2021, dari https://www.bps.go.id/subject/23/kemiskinan-dan-

ketimpangan.html\#: :text=Konsep\%20\%3A,yang\%20diukur\%20dari\%20sisi\%20pengelu $\underline{\operatorname{aran}}$

Badan Pusat Statistik. (n.d.-d). Pertumbuhan Ekonomi. Diakses tanggal 24 April 2021, dari https://sirusa.bps.go.id/sirusa/index.php/variabel/1435\#: :text=Perkembangan\%20produk si\%20barang\%20dan\%20jasa,PDRB\%20atas\%20dasar\%20harga\%20konstan.

Badan Pusat Statistik. (n.d.-e). Rata-rata Lama Sekolah (Tahun), 2017-2018. Diakses tanggal 16 Juli 2021, dari https://www.bps.go.id/indicator/26/415/2/-metode-baru-rata-rata-lamasekolah.html

Badan Pusat Statistik. (2020). Berita Resmi Statistik : Persentase Penduduk Miskin September 2019 turun menjadi 9,22 persen. Diakses tanggal 20 April 2021, dari https://www.bps.go.id/pressrelease/2020/01/15/1743/persentase-penduduk-miskinseptember-2019-turun-menjadi-9-22persen.html\#: :text=Garis\%20Kemiskinan\%20pada\%20September\%202019,(26\%2C25 \%20persen).

Badan Pusat Statistik Provinsi Papua. (2019a). Indikator Kesejahteraan Rakyat Provinsi Papua 2018/2019.

Badan Pusat Statistik Provinsi Papua. (2019b). Provinsi Papua dalam Angka 2019.

Badan Pusat Statistik Provinsi Papua. (2020a). Persentase Penduduk Miskin Menurut Kabupaten/Kota (Persen), 2018-2020. Diakses tanggal 20 April 2021, dari https://papua.bps.go.id/indicator/23/45/1/persentase-penduduk-miskin-menurutkabupaten-kota.html

Badan Pusat Statistik Provinsi Papua.(2020b). Persentase Penduduk Miskin Menurut Kabupaten/Kota (Persen), 2018-2020. Diakses tanggal 20 April 2021, dari https://papua.bps.go.id/indicator/23/45/1/persentase-penduduk-miskin-menurutkabupaten-kota.html

BBC News Indonesia. (12 Desember 2018). Proyek Infrastruktur Diklaim Masif, Tenaga Kerja Papua yang Terserap Tetap Minim. BBC News Indonesia. https://www.bbc.com/indonesia/indonesia-46530099

Direktorat Jenderal Perimbangan Keuangan. (2017). Kebijakan Dana Perimbangan: Evaluasi 2016 dan Pelaksanaan 2017. http://www.djpk.kemenkeu.go.id/wpcontent/uploads/2017/03/Bahan-Direktur-Daper.pdf.

United Nations. (2018). The 17 Goals. Diakses tanggal 20 April 20 2021, dari https://sdgs.un.org/goals 